\title{
Greig Cephalopolysyndactyly (GCPS) Contiguous Gene Syndrome in a Boy with a I 4 Mb Deletion in Region 7pI3-I4 Caused by a Paternal Balanced Insertion (5; 7) [Expression of Concern]
}

\author{
Schulz S, Volleth M, Muschke P, Wieland I, Wieacker \\ P. Appl Clin Genet. 2008;1:19-22.
}

The Editor-in-Chief and Publisher of The Application of Clinical Genetics wish to issue an Expression of Concern for the above published article.

The original article contained a clinical image of a child, who was the focus of this case study. It came to our attention that the article does not include a statement to confirm that consent for this image was obtained from the parent or guardian of the patient. We attempted to contact the authors of this article and their affiliated institution to confirm if consent to publish was obtained but despite multiple attempts have received no response. We would like to alert readers of this issue and advise that the image of the subject has been replaced with a grey box until further notice. This decision follows the recommendations of the Committee on Publication Ethics (COPE).

The Editor and Dove Medical Press make every effort to ensure publication ethics are upheld and are committed to supporting the high standards of The Application of Clinical Genetics journal.

\section{Publish your work in this journal}

The Application of Clinical Genetics is an international, peerreviewed open access journal that welcomes laboratory and clinical findings in the field of human genetics. Specific topics include: Population genetics; Functional genetics; Natural history of genetic disease; Management of genetic disease; Mechanisms of genetic disease;
Counselling and ethical issues; Animal models; Pharmacogenetics; Prenatal diagnosis; Dysmorphology. The manuscript management system is completely online and includes a very quick and fair peerreview system, which is all easy to use. Visit http://www.dovepress. com/testimonials.php to read real quotes from published authors. 